\title{
助詞 の習得過程
}

—「が」と「を」について—

池

語を機能・意味・形態などを基準として分類した場合， 助詞は日本語において特徴的なもののひとつであり, 時 枝文法の辞に含まれる語である。つまり, 助詞は独立し て意味をもたず，詞に付属してはじめて，語と語の関釈 を示したり, 語の意味を限定したりして, 意味をもつ語 である。したがって, 助詞を正確に使用するためには, その助詞のもつ論理的な記述性を把握し, 場面との適合 性を検討する能力が必要であると考えられ, 助詞は, 名 詞や動詞などのような詞に含まれる品詞と比較して, そ の習得が遅れ, また, 習得の過程も異なるであろうこと が推測される。

助詞の発達に関する研究には, 自由場面やそれに準じ た場面で話された助詞の初出年齢や使用数を分析したも の（永野, 1959 ; 大久保, 1967 ; 藤友, 1979 ; 池, 1979) と, 特定の助詞の理解や使用を扱った実験的色彩の強い もの（天野，1968；Hayashibe, 1975 ; 藤田ら, 1975 ; 秦野，1979）がある。

永野（1959）は, おもな助詞は満 3 歳までにはほぼ習 得できるとしており，大久保（1967）も同様の結果を得 ている。しかし, 天野 (1968) によれば, 助詞「を」と 「に」をどの状況でも理解できるのは 5 歳児でも $50 \%$ で あり, また, Hayashibe (1975) でも, 3 歳〜 6 歳の30 名のうち助詞「が」と「を」を完全に理解しているのは 7 名であり，その最年少児は 4 歳 5 か月であった。

このような習得年齢の差は場面設定の違いから生じて きたものと考えられ, 先行研究から, 自由な場面で自発 的に助詞を使用できるようになるのは 3 歳前後であるが, 助詞 (先行研究では格助詞の一部) の表わす関係を正確 に把握するようになるのは数年後のことであり， 5 歳児 でもまだ正確に把握していないものがかなりいることが 指摘できる。また, 助詞を文理解の手がかりとして用い るようになるまでの大きな枠組での習得の過程や, 特定 の助詞の習得年齢は, ほぼ明らかにされているといらこ とができる。

\footnotetext{
* 筑波大学心身障害学系
}

弘子*

しかし, 先行研究においては, まだ, それぞれの助詞 の習得過程を明らかにするまでにはいたっていない。本 研究は, 特定の助詞についてその習得過程を明らかにす るための手がかりを得ることを目的とする。

井上（1976）は，2つの名詞句と述語から成る文を文 の核として取り上げ, 助詞の「が」と「を」がこの文の 主語・目的語という一定の文法関係を示す役割を果たし ているとしており, 格助詞「が」と「を」は基本的な文 法関係を示すために使用されるということができる。

また「が」と「を」は使用回数も多く（藤友, 1979 ; 池, 1979), 初出年齢も比較的早い（大久保, 1967)。永 野（1959）は,「が」は 2 歳 2 か月,「を」は 2 歳 4 か月 でほぼ習得されるとしている。

しかし, すでに述べたように, これらの助詞は 5 歳児 でも完全にその表わす関係を理解しているとはいえず, MA 6 歳〜 7 歳11か月の普通児と知能障害児を一群とし て助詞の使用を分析した研究（池，1979）でも,「を」と 「が」を誤ることが多かった。

そこで, 研究対象の助詞として, 基本となる文で使用 され, 使用回数も多いが誤りも多い格助詞の「が」と

「を」を取り上げることとする。

池（1979）は，誤りの多い「が」を「を」に誤った例 と「を」を「が」に誤った例の分析から，誤りには助詞 とともに使用されている動詞の種類が関係している可能 性を示唆している。

また, Hayashibe (1975) は, 可逆文と非可逆文とい ら文の種類も,「が」と「を」の理解に関連のあること を示している。

したがって, 本研究は, 格助詞「が」と「を」に関し て, 助詞とともに使用される動詞の種類と, 助詞が使用 される文の種類を要因として, これらの助詞の正確な使 用の難易の分析を行い,「が」と「を」の習得過程に対 する手がかりを得ようとするものである。

なお, 本研究で「が」について述べる場合は, 特に記述 がなければ,「主語を表わす」用法の「が」を示し「を」につ いて述べる場合は, 「他動性の動作・作用の目的・目標」 
の「を」を示している（国立国語研究所，1951による）。

\section{方法}

\section{被験児}

被験児は, 絵画語い発達検査による語い年齢が 4 歳〜 7 歳11か月で, 評価点が $7 \sim 13$, つまり, 同一生活年齢 水準でその得点が 1 標準偏差内に入る幼児および児童で ある。なお，動作性の知能についても，大脇式精薄児用 知能検查またはコース立方体組合わせテスト（MA 5 歳 11か月までは前者, MA 6 歳以上は後者使用）とグッド イナフ人物画知能検查の少なくとも一方の IQ が 80 以上 のものに限定した。

TABLE 1 被験児の構成

\begin{tabular}{|c|c|c|c|c|c|c|}
\hline \multicolumn{3}{|c|}{ 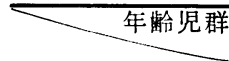 } & 4 墄児群 & 5 歳少群 & 6 歳児群 & 7 歳児群 \\
\hline \multirow{2}{*}{\multicolumn{2}{|c|}{ 被験児数 }} & 男 & 10 名 & 10 名 & 10 名 & 10 名 \\
\hline & & 女 & 10 名 & 10 名 & 10 名 & 10 名 \\
\hline 平 均 & \multicolumn{2}{|c|}{$\mathrm{CA}$} & $4: 10$ & $5: 5$ & $6: 5$ & $7: 2$ \\
\hline \multicolumn{3}{|c|}{ 平均語い年鹷 } & $4: 6$ & $5: 5$ & $6: 5$ & $7: 5$ \\
\hline \multirow{2}{*}{ 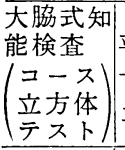 } & \multicolumn{2}{|c|}{ 平均 $\mathrm{MA}$} & $4: 4$ & $5: 2$ & $6: 4$ & $8: 0$ \\
\hline & \multicolumn{2}{|c|}{ 平均 $\mathrm{IQ}$} & 91 & 96 & 99 & 111 \\
\hline \multirow{2}{*}{$\begin{array}{l}\text { 人物画 } \\
\text { 知能検査 }\end{array}$} & \multicolumn{2}{|c|}{ 平均 MA } & $4: 10$ & $5: 5$ & $6: 5$ & $7: 3$ \\
\hline & \multicolumn{2}{|c|}{ 平均 IQ } & 101 & 101 & 101 & 102 \\
\hline
\end{tabular}

被験児は, 語い年齢により 4 歳児群 $(4$ 歳〜 4 歳11か 月), 5 歳児群 ( 5 歳 5 歳11か月), 6 歳児群 ( 6 歳 6 歳11か月), 7 歳児群（7 歳～ 7 歳11か月）の 4 年齢児 群に分けた。以下，年龄について述べる場合は語い年齢 をさす。各年齢児群の詳細は TABLE 1 に示してある。

\section{実験材料}

課題文は TABLE 3 に示してある。また，動詞の種類， 文の種類は，それぞれ，以下 TABLE 2 のように省略し て示す。

文を構成している名詞および動詞は，岩淵・村石編 「幼児の用語」から選択した。これは, 課題文で使用さ れた名詞と動詞が， 3 名の幼児のうち 2 名以上が満 5 歳 までに共通して使用し，使用回数も多い語であることを 意味する。

また，本研究で使用した可逆文は，「が」のかわりに 「を」または「を」のかわりに「が」を入れると，提示 された絵とは逆の関係を示す文であり，非可逆文は， 「が」のかわりに「を」または「を」のかわりに「が」 を入れると，提示された絵と逆の関係は示さず非文法的 になることが多い文であることを示している。

実験材料は, TABLE 3 に示した課題文と一致する絵 （B 5 判の大きさ。例をFIG. 1 に示す） と，周波数 300 $\mathrm{Hz}$ 以上をカットすることにより表現させる部分(TABLE 3 ののの部分）を歪んで聞き取れなくして課題文を録音 してあるテープを用いた。

TABLE 2 本研究で使用した省略した表現とその表わす意味

\begin{tabular}{|c|c|c|c|}
\hline 省 略 形 & 味 & 省 略 形 & 味 \\
\hline \multirow{3}{*}{ A 他動詞 } & \multirow{3}{*}{$\begin{array}{l}\text { 対応する自動詞が可能動詞 } \\
\text { である他動詞 }\end{array}$} & A 他動詞文 & A 他動詞を含む文 \\
\hline & & A 他 R文 & A 他動詞を含む R文 \\
\hline & & $\mathrm{A}$ 他 N文 & A 他動詞を含むN文 \\
\hline \multirow{3}{*}{ B 他動詞 } & \multirow{3}{*}{$\begin{array}{l}\text { 対応する自動詞がある他動 } \\
\text { 詞 }\end{array}$} & B 他動詞文 & B 他動詞を含む文 \\
\hline & & B 他 R文 & B 他動詞を含む R文 \\
\hline & & B 他 N文 & B 他動詞を含む N文 \\
\hline \multirow{3}{*}{ B 自動詞 } & \multirow{3}{*}{$\begin{array}{l}\text { 対応する他動詞がある自動 } \\
\text { 詞 }\end{array}$} & B 自動詞文 & B 自動詞を含む文 \\
\hline & & B自 $(R)$ 文 & $\mathrm{B}$ 他 $\mathrm{R}$ 文の他動詞に対応する自動詞を含む文 \\
\hline & & B 自 (N) 文 & $\mathrm{B}$ 他 $\mathrm{N}$ 文の他動詞に対応する自動詞を含む文 \\
\hline C 自動詞 & 対応する他動詞がない自動詞 & $\mathrm{C}$ 自動詞文 & C 自動詞を含む文 \\
\hline $\mathrm{R}$ 文 & 可 逆 文 & & \\
\hline $\mathrm{N}$ 文 & 非可逆文 & & \\
\hline
\end{tabular}


TABLE 3 課題文 （男坚の例）

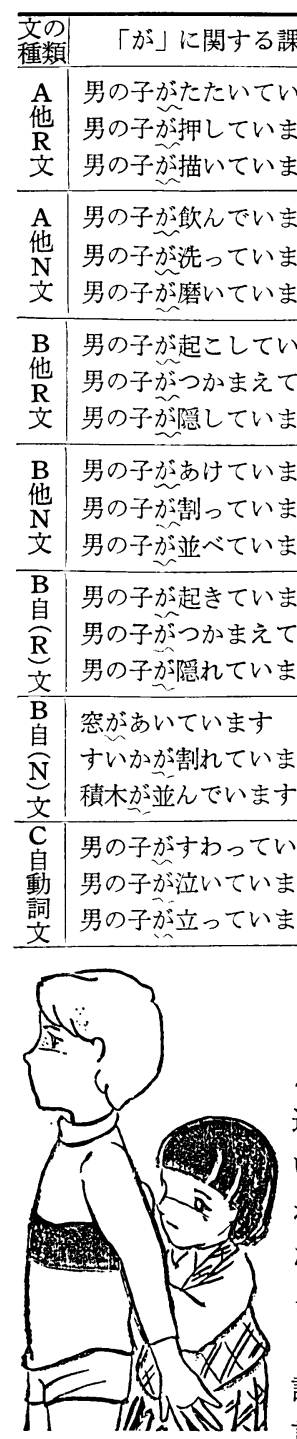

FIG. 1 実験材料の例

(「男の子が暚してい

ます」と一致する絵）

を」に関する課題文

男の子をたたいています

男の子を押しています

男の子を描いています

ジュースを飲んでいます

手を洗っています

靴を磨いています

男の子を起こしています

男の子をつかまえています

男の子恚嬡しています

空をあけています

すいかを割っています

積木を並べています

(いが表現させる部分)

\section{なす}

ています

ます

\section{ます}

ます

す

手 続

絵を提示し,「この絵の話が聞こ えてきますからよく聞いて言った 通り言ってください。聞こえにく いところがありますが絵をみれば わかりますから，自分で考えてく ださい。」と言い, テープレコー ダを聞くよう指示して, 練習を行 う。助詞の部分を省略したり, 助 詞以外の聞き取れる部分を違えて 言った場合は，それを指摘し，も ういちど練習を行う。練習後, テ スト課題に入る。テープを聞いた 後,なかなか答えない被験児には， 実験者が歪んで聞き取れない部分の前まで繰り返す。反 応しない,「わからない」と言う, 聞き取れる部分を違 えて言うなどの場合は, もらいちどテープを聞かせる。 なお, 各課題文はあらかじめランダムな順序に並べて ある。

\section{分析の方法}

分析は, 文の種類を単位に行い, その単位に含まれる 3つの課題文すべてに正答した場合を, その文の種類で 正答したとする。
正答以外の答, たとえば, 省略や助詞以外の部分を間 違えた場合などは，すべて誤答とする。ただし，文末の 「ています」の部分は誤っても他の部分が正しければ正 答とする。また，「が」を「は」と答えた場合，もっと も適切な助詞ではないことから，誤答として扱う。

差の検定には, Fisher の直接確率計算法を用い, 同一 の文の種類における隣接する年齢児群の差, および, 比 較した文の種類または助詞の種類における同年齢児群の 差について検討する。なお， $p<.05$ を有意差の基準とす る。

\section{結果と考察}

\section{全体的な発達傾向}

ここではまず，各被験児のそれぞれの文の種類におけ る結果を基礎にし，「が」と「を」の習得を考える場 合 有効であると思われる発達段階の設定を試みる。そして, 次に, 習得段階からみた各年齢児群の特徴を検討する。

（1）「が」の習得

「が」における詥った文の種類（以下文とする）の組 合わせ別の被験児数をTABLE 4 に示す。

TABLE 4 から

1） 1 種類の文にのみ誤っている場合，1名を除いては， $\mathrm{B}$ 他 $\mathrm{R}$ 文， B自 $(\mathrm{R})$ 文， B 自 $(\mathrm{N})$ 文のいずれかである。

2) 2 種類以上の文で誤っている場合, ほとんどの組合 わせにおいて B 他 R文か B 自 ( R) 文が含まれているが, 両文がいっしょに含まれているとは限らない。

3） B 自 $(\mathrm{N})$ 文は，1種類の文にのみ誤っている場合か ら含まれており，2 種類以上の文で誤っている場合に も含まれることがある。

4） C 自動詞文は，4種類以下の文で誤っている場合に はまったく含まれていない。

5）A他 R文，A他 N文，B他 N文には，一定の傾向は みられない。

ことが指摘できる。

このような結果から，「が」の習得段階として， 第 I 段階一すべての文において誤っている段階

第 II 段階—B $\mathrm{B}$ 他 R文， B 自 ( R) 文のいずれにも誤り， C 自動詞文を含むいくつかの文に正答し ている段階

第四段階一B他 R文，B自 $(\mathrm{R})$ 文，B自 $(\mathrm{N})$ 文のい ずれかに誤り，他の文はほぼ正答してい る段階

第 N 段階一すずての文において正答している段階 
TABLE 4 「が」における誤った文の種類の 組合わせ別の被験児数

\begin{tabular}{|c|c|c|}
\hline $\begin{array}{l}\text { 詥った } \\
\text { 文の種 } \\
\text { 類の数 }\end{array}$ & 誤った文の種類の組合わせ & $\begin{array}{l}\text { 被 鈳 } \\
\text { 光 }\end{array}$ \\
\hline 0 & & 33名 \\
\hline 1 & $\begin{array}{l}B \text { 他 } R \text { 文 } \\
B \text { 自 }(R) \text { 文 } \\
B \text { 自 }(N) \text { 文 } \\
A \text { 他 } R \text { 文 }\end{array}$ & $\begin{array}{r}10 \\
9 \\
3 \\
1\end{array}$ \\
\hline 2 & $\begin{array}{l}A \text { 他 } R \text { 文, } B \text { 他 } R \text { 文 } \\
A \text { 他 } N \text { 文, } B \text { 自 }(R) \text { 六 } \\
B \text { 他 } R \text { 文, } B \text { 自 }(R) \text { 文 } \\
B \text { 他 } R \text { 文, } B \text { 自 }(N) \text { 文 } \\
B \text { 他 } N \text { 文, } B \text { 自 }(N) \text { 文 }\end{array}$ & $\begin{array}{l}1 \\
1 \\
1 \\
1 \\
1\end{array}$ \\
\hline 3 & $\begin{array}{l}\mathrm{A} \text { 他 } \mathrm{R} \text { 文, } \mathrm{B} \text { 他 } \mathrm{R} \text { 文. } \mathrm{B} \text { 自 }(\mathrm{R}) \text { 文 } \\
\mathrm{A} \text { 他 } \mathrm{R} \text { 文, } \mathrm{B} \text { 他 } \mathrm{R} \text { 文, } \mathrm{B} \text { 他 } \mathrm{N} \text { 文 } \\
\mathrm{A} \text { 他 } \mathrm{N} \text { 文, } \mathrm{B} \text { 他 } \mathrm{R} \text { 文, } \mathrm{B} \text { 他 } \mathrm{N} \text { 文 } \\
\mathrm{B} \text { 他 } \mathrm{R} \text { 文, } \mathrm{B} \text { 自 }(\mathrm{R}) \text { 文, } \mathrm{B} \text { 自 }(\mathrm{N}) \text { 文 }\end{array}$ & $\begin{array}{l}2 \\
1 \\
1 \\
1\end{array}$ \\
\hline 4 & $\begin{array}{l}A \text { 他 } R \text { 文, } A \text { 他 } N \text { 文, } B \text { 他 } R \text { 文, } \\
B \text { 自 }(R) \text { 文 } \\
A \text { 他 } N \text { 文, B 他 } R \text { 文, } B \text { 自 }(R) \text { 文, } \\
B \text { 自 }(N) \text { 文 }\end{array}$ & 1 \\
\hline 5 & $\begin{array}{l}A \text { 他 } \mathrm{R} \text { 文, } \mathrm{A} \text { 他 } \mathrm{N} \text { 文, B 他 } \mathrm{R} \text { 文, } \\
\mathrm{B} \text { 自 }(\mathrm{R}) \text { 文, } \mathrm{B} \text { 自 }(\mathrm{N}) \text { 文 } \\
\mathrm{A} \text { 他 } \mathrm{N} \text { 文, } \mathrm{B} \text { 他 } \mathrm{R} \text { 文, B 自 }(\mathrm{R}) \text { 文, } \\
\mathrm{B} \text { 自 }(\mathrm{N}) \text { 文, } \mathrm{C} \text { 自動詞文 }\end{array}$ & 1 \\
\hline 6 & $\begin{array}{l}\mathrm{A} \text { 他 } \mathrm{N} \text { 文, } \mathrm{B} \text { 他 } \mathrm{R} \text { 文, } \mathrm{B} \text { 他 } \mathrm{N} \text { 文, } \\
\mathrm{B} \text { 自 }(\mathrm{R}) \text { 文, B 自 }(\mathrm{N}) \text { 文, C 自動詞文 }\end{array}$ & 2 \\
\hline 7 & & 8 \\
\hline
\end{tabular}

を設定することができる。

80名の被験児のうち, 他の被験児とは詔答の組合わせ が非常に異なる 5 名はこの中に含まれていない。

第I段階にある被験児の誤りの内容をみると，「が」 「を」「に」のような使用頻度が高い助詞（藤友，1979； 池，1979）が混乱していると考えられる被験児と，「が」 の省略とこのような混乱の両方がみられる被験児がいる ことがわかる。発達的には, 助詞が使用される前に省略 される時期がある（永野，1959；大久保，1973）ことか ら，第 I 段階には，(1)助詞が省略される段階 (2)助詞の 省略と使用頻度が高い助詞の混乱がみられる段階 (3)使 用頻度が高い助詞の混乱がみられる段階の 3 つの下位段 階が考えられる。

第 II 段階では，正答のなかにC 自動詞文が必ず含まれ
ている。自動詞は「が」とともに使用されることが多い ことから，自動詞を含む文は正答することが容易である と考えられる。しかし, B 自動詞文の場合, 使用されて いる自動詞が対応する他動詞をもっているため，自動詞 と他動詞が分化していなければ，自動詞を含む文であっ ても「が」の使用が必ずしも容易であるとは限らない。 他動詞は「を」とともに使用されることも多いからであ る。一方，C自動詞文の場合，使用されている自動詞は 対応する他動詞がないことから，比較的早く「が」を正 確に使用できるようになるものと考えられる。

また，第四段階では, 誤答のなかに B 他 R文と B 自 ( R) 文が必ず含まれている。B他 R文の場合, 助詞と自 動詞・他動詞の相違, 提示された絵の中の 2 つの名詞 (「男の子」と「女の子」) の関係の把握のしかたにより, 4 つの文で表わすことができる課題文が 3 課題文中 2 課 題文含まれている。たとえば，「男の子が隠しています」 を例にとると，(1)男の子が隠しています（2)男の子に隠 れています (3女の子が隠れています（4)女の子を隠し ていますの 4 文汁同じ場面を表わしている (FIG.1参照)。 そして, $\mathrm{B}$ 自 $(\mathrm{R})$ 文の 3 課題文中 2 課題文は, $\mathrm{B}$ 他 $\mathrm{R}$ 文 と非常に類似した場面を表わしている。たとえば，B他 R文の「男の子が隠しています」の逆を表わす文「男の 子を隠しています」は， B 自 (R)文の「男の子が隠れて います」と同じ場面を表わしており，B自 $(\mathrm{R})$ 文もやは り，助詞と自動詞・他動詞の相違, 提示された絵の中の 2 つの名詞の関倸の把握のしかたにより，4つの文で表 わすことができる課題文が含まれている。このように， B他 R文とB自 $(\mathrm{R})$ 文は，同じ場面を類似した 4 つの文 で表現できる課題文が多いため, 全体が混乱し,「が」の 正確な使用がむずかしくなったと考えられる。

第 II 段階では，B他 R文と B 自 (R) 文の両文に誤りが みられたが，第四段階ではいずれか一方のみを誤ってい る。第四段階にある被験児で $\mathrm{B}$ 他 R 文が誤りである被験 児をみると，14名中10名は「が」を「を」に誤っていた。 この結果から，これらの被験児は，(1自動詞には「が」 を使用し，他動詞は「が」と「を」が混乱している (2) 自動詞には「が」を使用し，他動詞には「を」を使用し ているという2つの可能性が考えられる。(1)であれば, B他R文の「を」の使用も誤っていると考えられ，(2) 場合は，B他 R文の「を」の使用は正答していると考元 られる。10名の被験児の B他 R文の「を」の使用の結果 をみると，4名は「を」を「が」に誤っており，5名は 正答していた。そして, 誤っていた 4 名は 4 歳児群と 5 歳児群, 正答していた 5 名中 4 名は 7 歳児群の被験児で あった。したがって，第䀴段階で B 他 R文にのみ誤って 
TABLE 5 「が」における各年齢児群に関する 段階別の被験児数

\begin{tabular}{|c|c|c|c|c|}
\hline $\begin{array}{l}\text { 段階 } \\
\text { 年数 } \\
\text { 罗群 }\end{array}$ & 第 I 段階 & 第 II 段階 & 第 III 段階 & 第 $N$ 匢湝 \\
\hline 4 歳览群 & 5名 & 2名 & 6名 & 5名 \\
\hline 5 歳児群 & 2 & 3 & 7 & 6 \\
\hline 6 歳児群 & 1 & 2 & 6 & 10 \\
\hline 7 歳児群 & 0 & 0 & 8 & 12 \\
\hline
\end{tabular}

TABLE 6 「を」における誤った文の種類の 組合わせ別の被験児数

\begin{tabular}{|c|c|c|}
\hline $\begin{array}{l}\text { 詥った } \\
\text { 齐の種 } \\
\text { 類の数 }\end{array}$ & 誤った文の種類の組合わせ & $\begin{array}{l}\text { 被 験 } \\
\text { 罗 数 }\end{array}$ \\
\hline 0 & & 22名 \\
\hline \multirow{4}{*}{1} & $\mathrm{~B}$ 他 $\mathrm{R}$ 文 & 11 \\
\hline & $A$ 他 $\mathrm{R}$ 文 & 8 \\
\hline & A 他 $\mathrm{N}$ 文 & 2 \\
\hline & $\mathrm{B}$ 他 N文 & 2 \\
\hline \multirow[t]{2}{*}{2} & $\mathrm{~A}$ 他 $\mathrm{R}$ 文， B 他 $\mathrm{R}$ 文 & 12 \\
\hline & $\mathrm{A}$ 他 $\mathrm{N}$ 文, B 他 $\mathrm{N}$ 文 & 2 \\
\hline \multirow{3}{*}{3} & $\mathrm{~A}$ 他 $\mathrm{R}$ 文, $\mathrm{B}$ 他 $\mathrm{R}$ 文, $\mathrm{B}$ 他 $\mathrm{N}$ 文 & 10 \\
\hline & $A$ 他 $\mathrm{R}$ 文， $\mathrm{A}$ 他 $\mathrm{N}$ 文， $\mathrm{B}$ 他 $\mathrm{R}$ 文 & 1 \\
\hline & $A$ 他 $\mathrm{R}$ 文, $\mathrm{A}$ 他 $\mathrm{N}$ 文, $\mathrm{B}$ 他 $\mathrm{N}$ 文 & 1 \\
\hline 4 & & 9 \\
\hline
\end{tabular}

いる場合, (1), 次いで(2) 2 つの下位段階を考えること ができる。

また， B 自 ( R) 文汇諨っている場合, 10名の被験児の すべてが「男の子（女の子）がつかまっています」にの み誤っており，このうち6名は「に」に誤っていた。こ れらの被験児は,「つかまる」という自動詞の場合,

「に」とともに使用することが定着していることが考え られ, 助詞と動詞の結びつきが示唆される。また, 残り の4名は「を」に誤っていた。男の子（女の子）がつか まっています」と「男の子（女の子）をつかまえていま す」は同じ場面を表わしている。これらの被験児はすべ て，B他 R文の「を」の使用に含まれている後者の課題 文では正答していることから，4名は，「つかまる」の 場合, 自動詞を他動詞として把握している可能性が考え られる。

B 自 $(\mathrm{N})$ 文は, 1 種類の文にのみ誤っている場合から 含まれている。B自 $(\mathrm{N})$ 文は, 他の文が「男の子」また は「女の子」を主語としているのに対し「空」「すいか」
「積木」を主語としている。これらの名詞は，「男の子」 「女の子」と比べ，目的語になることが多い名詞である。 したがって, 名詞と助詞の結びっきが強い場合,「を」 に誤ると考えられ，数は少ないが, 名詞と助詞の結びつ きにより反応している被験児がいる可能性が示唆される。

次に, 各年齢児群に関する段階別の被験児数を TABLE 5 に示す。

「が」の習得を 4 段階に分けると，それぞれの年㱓児 群において特に優勢である段階を見出すことはできな いし，年踚の増加に伴う一定の傾向も第 I 段階亡第 $N$ 段 階においてしか得られない。そこで，第 I 段階々第 II 段 階をまとめ， B他 R文と B 自 $(\mathrm{R})$ 文の両文に詔っている 前段階とし，第四段階と第 $N$ 段階をまとめ，B他 $R$ 文と B自 $(\mathrm{R})$ 文のいずれか一方に誤るか，両文とも正答して いる後段階としてみた。そうすると，4段階に分けた場 合，どの段階にも属さなかった 5 名もどちらかの段階に 属し，80名の被験児のうち，後段階に属する被験児は， 4 歳児群 $60 \% ， 5$ 歳児群 $70 \% ， 6$ 歳児群 $80 \% ， 7$ 歳児群 $100 \%$ となった。

以上の点から，「が」の習得段階については，個々の 被験児について習得の段階を追う場合は 4 段階に分け， 各年龄览群の特徴をとらえたり，属している年齢児群に おける被験児の位置をとらえようとする場合は 2 段階に 分けるといらように，機能的に考えたほうがいいと考え られる。

（2）「を」の習得

誤った文の種類の組合わせ別の被験児数を TABLE 6 呩す。

TABLE 6 から，「を」の習得の段階として，

第I 段階一すすへての文において誤っている段階

第 II 段階一 $\mathrm{A}$ 他 $\mathrm{N}$ 文にのみ正答している段階

第四段階一 $\mathrm{A}$ 他 $\mathrm{N}$ 文と $\mathrm{B}$ 他 $\mathrm{N}$ 文に正答している段階

第 $\mathrm{N}$ 段階一 $\mathrm{A}$ 他 R文， $\mathrm{A}$ 他 $\mathrm{N}$ 文， B 他 $\mathrm{N}$ 文の 3 文吕, $\mathrm{A}$ 他 $\mathrm{N}$ 文, B他 R文, B 他 $\mathrm{N}$ 文の 3 文に 正答している段階

第V段階一すべての文において正答している段階

を設定することができる。

80名の被験児のうち, 他の被験児とは誤答の組合わせ が異なる8名はこの中に含まれていない。

第 I 段階では,「が」の場合と同じく，(1)助詞が省略 される段階 (2)助詞の省略と使用頻度が高い助詞の混乱 
TABLE 7 「を」における各年齢児群に関する 段階別の被験児数

\begin{tabular}{c|c|c|c|c|c}
\hline $\begin{array}{c}\text { 年段階 } \\
\text { 児群 }\end{array}$ & 第 I 段階 & 第 II 段階 & 第 III 段階 & 第 N 段階 & 第 V 段階 \\
\hline 4 歳児群 & 5 名 & 3 名 & 5 名 & 2 名 & 1 名 \\
\hline 5 歳览群 & 4 & 5 & 2 & 4 & 4 \\
\hline 6 歳児群 & 0 & 2 & 3 & 6 & 7 \\
\hline 7 歳児群 & 0 & 0 & 2 & 7 & 10 \\
\hline
\end{tabular}

TABLE 8 「が」と「を」における各年略坚群に 関する段階別の被験児数

\begin{tabular}{c|c|c|c|c}
\hline $\begin{array}{c}\text { 段階 } \\
\text { 年齢 }\end{array}$ & 前一前段階前一後段階 & 後一前段階 & 後一後段階 \\
\hline 4 歳児群 & 6 名 & 1 名 & 8 名 & 2 名 \\
\hline 5 歳児群 & 3 & 2 & 8 & 6 \\
\hline 6 歳児群 & 1 & 2 & 4 & 11 \\
\hline 7 歳児群 & 0 & 0 & 2 & 17 \\
\hline
\end{tabular}

がみられる段階 (3)使用頻度が高い助詞の混乱がみられ る段階の 3 つの下位段階が考えられる。

第 II 段階と第 III 段階においては N文の習得がなされ, 第 $N$ 段階と第 $\mathrm{V}$ 段階で $\mathrm{R}$ 文の習得がなされる。したがっ て，N文は R文より「を」の習得が早いことが指摘でき る。これは，R文は，「を」のかわりに「が」を使用す ると, 提示された絵とは逆の関係を表わす文になる文, $\mathrm{N}$ 文は, 「を」以外の助詞を使用すると, 非文法的な文 になる文であることによると考えられる。また，N文の 場合,「を」との結びつきが強い名詞が目的語となって いることも, 少数の被験児にとっては容易な要因となっ たことが考えられる。

また, 第 II 段階では A 他 $\mathrm{N}$ 文が, 第 III 段階では $\mathrm{B}$ 他 $\mathrm{N}$ 文が習得され，同じ $\mathrm{N}$ 文であっても $\mathrm{A}$ 他 $\mathrm{N}$ 文が容易であ ることがわかる。B他 N文は, 使用された他動詞が対応 する自動詞をもっており, 自動詞と他動詞が分化してい なければ，「が」を使用しても非文法的であると感じる ことはない。一方, A他 N文で使用された他動詞は対応 する自動詞をもっていない。このような理由から， A 他 $\mathrm{N}$ 文は B 他 $\mathrm{N}$ 文より「を」の正確な使用が容易であると 考えられる。

次に, 各年齢児群に関する段階別の被験児数をTABLE 7 に示す。

「を」の習得を 5 段階に分けた場合, それぞれの年齢
児群において特に優勢である段階を見出すことはできな いし，年龄の増加に伴う一定の傾向も，第 II 段階と第 III 段階では得られない。そこで, 第 I 段階, 第 II 段階, 第 四段階をまとめ, R文はすべて誤答している前段階と， 第 $\mathrm{N}$ 段階と第 V 段階をまとめ， N文はすべて正答し， R 文は 1 種類以上の文に正答している後段階にしてみた。 そうすると， 5 段階に分けた場合どの段階にも属さなか った被験児のうち，4 歳児群の 1 名は前段階に属するよ うになり，73名の被験児のうち後段階に属する被験児は， 4 歳児群約 $18 \% ， 5$ 歳児群約 $42 \% ， 6$ 歳児群約 $72 \% ， 7$ 歳児群約 $89 \%$ となった。

以上の点から,「が」と同じく,「を」の習得段階につ いても， 5 段階の分け方と 2 段階の分け方を，目的に応 じて使用したほうがいいと考えられる。

\section{(3)「が」と「を」の習得}

「が」と「を」をあわせてとらえようとする場合， 「が」を 4 段階，「を」を 5 段階に分けると，「が」と 「を」のそれぞれの段階の組合わせにおける被験児数は 少なく, 複雑で, 一定の傾向を得ることもできない。し たがって，ここでは，「が」と「を」とも，2段階に分 けて考えることとする。

「が」と「を」とも2 段階に分けた場合, 前一前段階 (「が」前段階，「を」前段階であることを意味し，以下 同様に示す） 10 名, 前一後段階 5 名, 後一前段階 22 名, 後一後段階36名であった。

この結果から，「を」より「が」の習得が容易である 被験児が多く,「が」と「を」の習得に際しては, 前一 前段階, 後一前段階, 後一後段階とす寸むことが推測さ れる。

次に, 各年齢児群に関する段階別の被験児数をTABLE 8 に示す。

TABLE 8 から， 4 歳児群注前一前段階之後一前段階, 5 歳児群は後一前段階と後一後段階が多く, 6 歳児群で は後一後段階がもっとも多くなり，7歳児群になるとほ とんどの被験児が後一後段階となることが指摘できる。 したがって，7歳児群では，ほとんどの被験児が「が」 と「を」をほぼ習得しているということができる。

発達段階の設定においては,「が」は 4 段階,「を」は 5段階に分けられた。これは, 各被験児の結果を基礎に して発達段階を設定したために生じたものであり, 機械 的に同一の段階数を設定するよりも意味があると考えら れたためである。また，「が」と「を」の関係を検討す る場合には, 両助詞とも，2段階にまとめられた。これ も，この方法がより意味があると考えたためである。 


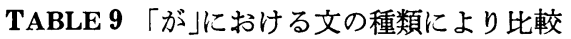
した同年齢児群の差の検定結果

\begin{tabular}{|c|c|c|c|c|}
\hline 年略纭群 & & & & \\
\hline $\begin{array}{l}\text { 比較 } \\
\text { た文 } \\
\text { の種類 }\end{array}$ & 4 歳児群 & 5 葴児群 & 6 歳児群 & 7 歳児群 \\
\hline 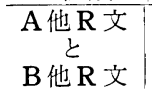 & NS & NS & NS & NS \\
\hline $\begin{array}{l}\text { A他N文 } \\
\text { B } \\
\text { B他 } N \text { 文 }\end{array}$ & NS & NS & NS & NS \\
\hline $\begin{array}{l}\mathrm{A} \text { 他 } \mathrm{R} \text { 文 } \\
\mathrm{A} \\
\mathrm{A} \text { 他 } \mathrm{N} \text { 文 }\end{array}$ & NS & NS & NS & NS \\
\hline $\begin{array}{l}\mathrm{B} \text { 他 } \mathrm{R} \text { 文 } \\
\mathrm{B} \\
\mathrm{B} \text { 他 } \mathrm{N} \text { 文 }\end{array}$ & NS & $\mathrm{P}<.020$ & $\mathrm{P}<.046$ & NS \\
\hline $\begin{array}{c}\mathrm{B} \text { 他 } \mathrm{R} \text { 文 } \\
\qquad \\
\mathrm{B} \text { 自 }(\mathrm{R}) \text { 文 }\end{array}$ & NS & NS & NS & NS \\
\hline 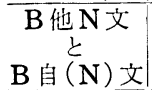 & NS & NS & NS & NS \\
\hline $\begin{array}{l}\text { B自 (R) } \\
\text { C 文 } \\
\text { C 自動詞文 }\end{array}$ & NS & NS & NS & NS \\
\hline $\begin{array}{l}\text { B 自 }(\mathrm{N}) \text { 文 } \\
\text { C 自動詞文 }\end{array}$ & NS & NS & NS & NS \\
\hline
\end{tabular}

NS：有意差なし

\section{文の種類による比較}

ここでは，各年齢児群に分けて文の種類による正答児 数の比較を行い, 正確な使用の難易に影響を及ぼしてい る要因を検討する。

\section{（1）「が」の使用}

それぞれの文の種類における「が」の正答児数を FIG. 2 に示す。また，文の種類により比較した同年齢児群の 差の検定結果を TABLE 9 亿示す。隣接する年齢児群間 で有意差のある文の種類はなかった。

\section{a . A 他動詞文と B 他動詞文の比較}

ここでは，A他 R文と B他 R文，A他 $\mathrm{N}$ 文と B他 $\mathrm{N}$ 文 に分けて，それぞれ比較することによって，A他動詞文 と B他動詞文の比較を行う。

A 他R文と B 他 R文を比較すると, TABLE 9 と, FIG. 2 から，同年齢児群で有意差のある年龄児群はないが， 4 年齢児群を通して， $\mathrm{A}$ 他 $\mathrm{R}$ 文が正答児数が多いことが わかる。

また，A他N文と B他N文を比較すると，FIG. 2 から， 4 年齢児群を通して, ほとんど正答児数に差がないこと がわかる。

したがって，A他動詞文と B 他動詞文を比較すると， $\mathrm{A}$ 他 $\mathrm{N}$ 文と $\mathrm{B}$ 他 $\mathrm{N}$ 文では差がなく, $\mathrm{A}$ 他 $\mathrm{R}$ 文と $\mathrm{B}$ 他 $\mathrm{R}$ 文 では， A他 R文が正確な使用が容易な傾向がある，とい
うことができる。

先に述べたように, B 他 R 文の場合, 3 課題文中 2 課 題文は，1つの場面を， 2 つの名詞の把握の仕方などに より，類似した 4 つの文で表現できる場面を表わす文で あり，混乱しやすい文である。

したがって，A他動詞文と B 他動詞文を比較した場合, 対応する自動詞がある動詞を含む文であるかどうかのみ により，正確な使用の難易に差があるのではなく，自動 詞・他動詞の違いと助詞の違いによって, いくつかの文 で表わすことのできる状況を表わす文であるかどうかに よると考えられる。

b. R文と N文の比較

ここでは，A他 R文と A他 $\mathrm{N}$ 文， B 他 R 文と B 他 $\mathrm{N}$ 文 に分けて，それぞれ比較することによって， R文と $\mathrm{N}$ 文 の比較を行う。

$\mathrm{A}$ 他 R文と A他 N文を比較すると，FIG. 2 から， 4 年 齢児群を通して，ほとんど正答児数に差がないことがわ かる。

また，B他R文と B他N文を比較すると，FIG. 2 と TABLE 9 から， 4 年齢児群を通して，B他 N文が正答児 数が多く, 5 歳児群と 6 歳児群で有意差があることがわ かる。

したがって， R文と N文を比較すると，「が」のかわ りに「を」を使用しても，提示された絵とは逆の関係を 表わすのみである R文が，非文法的となるN文よりむず かしいことが予測されるが， R文と N文で差があったの は， B他 $\mathrm{R}$ 文と $\mathrm{B}$ 他 $\mathrm{N}$ 文の間のみであった。

この結果から，「が」の使用に関しては， R文と N文 の違いのみにより差が生じるのではなく,すでに述べた ように，その文が表わしている場面が類似したいくつか の文で表わすことができる状況である場合，特に正確な 使用がむずかしいと考えられる。

c. B 他動詞文と B 自動詞文の比較

ここでは, $\mathrm{B}$ 他 $\mathrm{R}$ 文と $\mathrm{B}$ 自 $(\mathrm{R})$ 文, $\mathrm{B}$ 他 $\mathrm{N}$ 文と $\mathrm{B}$ 自 $(\mathrm{N})$ 文に分けて，それぞれ比較することによって，B他 動詞文と B 自動詞文の比較を行う。

B他 R文と B 自 (R) 文を比較すると, FIG. 2 から， 4 年龄児群を通して，ほとんど正答児数に差がないことが わかる。

また，B他N文と B 自 (N) 文を比較すると, TABLE 9 と FJG. 2 から, 同年齢児群で有意差のある年齢児群は ないが， B他 N文が正答児数が多い傾向にあることがわ かる。

したがって，B他動詞文と B 自動詞文を比較すると， $\mathrm{B}$ 他 $\mathrm{R}$ 文と $\mathrm{B}$ 自 $(\mathrm{R})$ 文では差がなく, $\mathrm{B}$ 他 $\mathrm{N}$ 文と $\mathrm{B}$ 自 


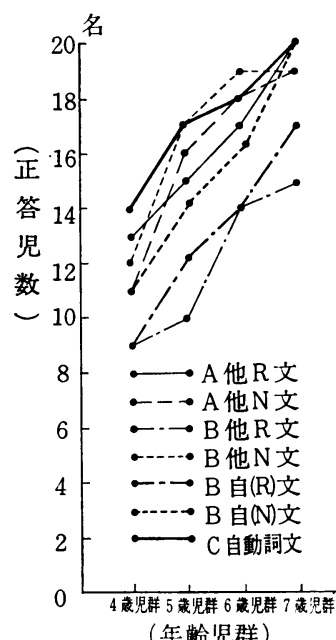

FIG. 2 それぞれの文にお ける「が」の正答児数

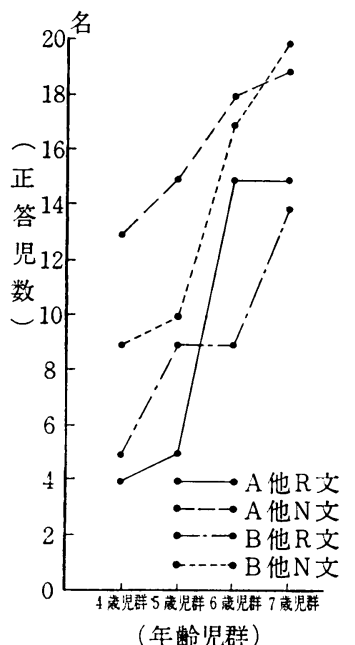

FIG. 3 それぞれの文にお ける「を」の正答児数

（N)文では，B他N文が正確な使用が容易な傾向がある， ということができる。

$\mathrm{B}$ 他 $\mathrm{N}$ 文と B 自 $(\mathrm{N})$ 文の相違のひとつは，B他 $\mathrm{N}$ 文は 他動詞文であり， B 自 $(\mathrm{N})$ 文は自動詞文である点である。 他動詞は「を」とともに使用されることも多いが，自動 詞は「が」とともに使用されることが多い。したがって， $\mathrm{B}$ 自 $(\mathrm{N})$ 文が正確な使用が容易であると予測されるにも かかわらず，B他N文のほうが容易であった。

$\mathrm{B}$ 他 $\mathrm{N}$ 文と B 自 $(\mathrm{N})$ 文のもうひとつの相違は, 主語に 使用された名詞の種類が異なっており，B自 $(\mathrm{N})$ 文の主 語は，B他N文の主語より目的語になることが多い名詞， すなわち，「を」とともに使用されることが多い名詞が 主語になっている点である。この相違により， B 自 $(\mathrm{N})$ 文が誤りやすくなったものと考えられる。

したがって，B他動詞文と B 自動詞文を比較した場合， 他動詞であるか自動詞であるかにより正確な使用の容易 さに差があるといらよりも，主語がどんな種類の名詞で あるかにより，差が生じてくると考えられる。

\section{d. B 自動詞文と C 自動詞文の比較}

ここでは，B自 $(\mathrm{R})$ 文と $\mathrm{C}$ 自動詞文, B 自 $(\mathrm{N})$ 文と C 自動詞文に分けて，それぞれ比較することによって，B 自動詞文と C 自動詞文の比較を行う。

$\mathrm{B}$ 自 $(\mathrm{R})$ 文と C 自動詞文を比較すると, TABLE 9 と FIG. 2 から，同年齢児群で有意差のある年齢児群はない が，4 年齢児群を通して，C自動詞文が正答児数が多い ことがわかる。

また， B自 $(\mathrm{N})$ 文と C 自動詞文を比較すると, TABLE 9 と FIG. 2 から, 同年龄児群で有意差のある年齢児群

TABLE 10 「を」における文の種類により比較 した同年齢児群の差の検定結果

\begin{tabular}{|c|c|c|c|c|}
\hline 年歯少群 & & & & \\
\hline $\begin{array}{l}\text { 比較 } \\
\text { した文 } \\
\text { の種類 }\end{array}$ & 4 䇦児群 & 5 歳児群 & 6 歳児群 & 7 歲児群 \\
\hline $\begin{array}{l}\mathrm{A} \text { 他 } \mathrm{R} \text { 文 } \\
\stackrel{\text { r }}{\mathrm{B}} \text { 他 } \mathrm{R} \text { 文 }\end{array}$ & NS & NS & NS & NS \\
\hline $\begin{array}{l}\text { A 他 N文 } \\
\text { B 他 } \\
\text { 文文 }\end{array}$ & NS & NS & NS & NS \\
\hline 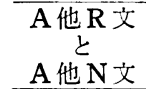 & $\mathrm{P}<.005$ & $\mathrm{P}<.002$ & NS & NS \\
\hline $\begin{array}{l}\mathrm{B} \text { 他 } \mathrm{R} \text { 文 } \\
\text { と } \\
\mathrm{B} \text { 他 } \mathrm{N} \text { 文 }\end{array}$ & NS & NS & $\mathrm{P}<.009$ & $\mathrm{P}<.010$ \\
\hline
\end{tabular}

はないが，C自動詞文が正答児数が多い傾向にあること がわかる。

したがって，B 自動詞文と C 自動詞文を比較すると, $\mathrm{B}$ 自 $(\mathrm{R})$ 文と $\mathrm{C}$ 自動詞文, $\mathrm{B}$ 自 $(\mathrm{N})$ 文と $\mathrm{C}$ 自動詞文とも に， C 自動詞文が正確な使用が容易な傾向があるという ことができる。

これは，すでに述べたように，C自動詞は，B自動詞 とは異なり，対応する他動詞をもたないし，「が」とと もに使用されることがほとんどであることによると考え られる。

（2）「を」の使用

それぞれの文の種類における「を」の正答児数を FIG. 3 に示す。また, 文の種類により比較した同年龄児群の 差の検定結果をTABLE 10 に示す。隣接する年齢児群間 で有意差があるのは $\mathrm{A}$ 他 $\mathrm{R}$ 文と $\mathrm{B}$ 他 $\mathrm{N}$ 文で，いずれも， 5 歳児群と 6 歳児群の間であった（A 他 $\mathrm{R}$ 六 $: \mathrm{P}<.002$, $\mathrm{B}$ 他 $\mathrm{N}$ 文 : $\mathrm{P}<.020)$ 。

a. A 他動詞文と B 他動詞文の比較

ここでは，A他 $\mathrm{R}$ 文と $\mathrm{B}$ 他 $\mathrm{R}$ 文， $\mathrm{A}$ 他 $\mathrm{N}$ 文と $\mathrm{B}$ 他 $\mathrm{N}$ 文 に分けて，それぞれ比較することによって，A他動詞文 と B 他動詞文の比較を行う。

A 他R文と B 他R文を比較すると, TABLE 10 と FIG. 3 から, 同年齢児群で有意差のある年齢坚群はなく, 一 貫した傾向もないことがわかる。

また，A他 N文と B 他 N文を比較すると， TABLB 10 と FIG. 3 から, 同年齢児群で有意差のある年齢児群法 ないが，A他 N文が正答児数が多い傾向にあることがわ かる。

したがって，A他動詞文と B 他動詞文を比較すると， $\mathrm{A}$ 他 $\mathrm{N}$ 文と $\mathrm{B}$ 他 $\mathrm{N}$ 文の場合は, $\mathrm{A}$ 他 N文が正確な使用が 容易な傾向があるが，A他 R文と B 他 R文には一貫した 
傾向はないということができる。

$\mathrm{A}$ 他 R文で使用された他動詞は可能動詞をもっている。 可能動詞は,「絵が描ける」のように,「対象語を表わす」 用法の「が」とともに用いられることが多い。この「が」 は,「目的語を表わす」とする説もあり（久野，1973）, 「が」の「対象語を表わす」用法と, 正しいとされた 「を」の「動作・作用の目的・目標」の用法は, 非常に 類似した用法であるといらことができる。

したがって，A他R文の場合，「を」を正確に使用す るためには，「を」の表わす関係を把握するとともに，

「対象語を表わす」用法の「が」との差も把握しなけれ ばならない。

$\mathrm{B}$ 他 $\mathrm{R}$ 文の場合, 本研究で用いた $\mathrm{B}$ 他 $\mathrm{R}$ 文, 名詞（目 的語 $)+「 を 」 十$ 他動詞，たとえば，「男の子を隠していま

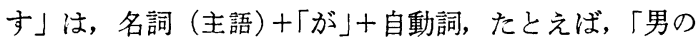
子が隠れています」と同じ状況を示している。つまり， $\mathrm{B}$ 他 R文は, 自動詞と他動詞の分化ができていなければ, 「を」と「が」を使い分けることができない文である。 したがって，B他R文の場合，「を」を正確に使用する ためには，「を」の表わす関係の把握とともに，自動詞 と他動詞の分化が必要となる。

このように，A他 $\mathrm{R}$ 文と $\mathrm{B}$ 他 $\mathrm{R}$ 文には，ともに，正答 するためのいくつかの条件があり, これらの条件の相違 により，正答児数の増加のパターンに相違が生じてきた と考えられる。

$\mathrm{A}$ 他 $\mathrm{N}$ 文が $\mathrm{B}$ 他 $\mathrm{N}$ 文より容易な理由についてはすでに 述べた。

\section{b. R文と N文の比較}

ここでは，A他 R文とA他 $\mathrm{N}$ 文， B 他 R文と B 他 $\mathrm{N}$ 文 に分けて，それぞれ比較することによって， R文と $\mathrm{N}$ 文 の比較を行う。

A 他 R文とA他N文を比較すると， FIG. 3 と TABLE 10 から， 4 年龄児群を通して，A他 $\mathrm{N}$ 文が正答児数が多 く, 4 歳児群と 5 歳児群で有意な差があることがわかる。 また，B他R文と B 他N文を比較すると， FIG. 3 と TABLE 10 から，4 年齢児群を通して B 他 N文が正答児 数が多く, 6 歳児群と 7 歳児群で有意な差があることが わかる。

したがって，A他R文と A他 N文を比較した場合， B 他 R文と $\mathrm{B}$ 他 $\mathrm{N}$ 文を比較した場合ともに， N文が R文よ り使用が容易であるということができる。この理由につ いては,すでに述べた。

また， R文と N文で誤りの種類を比較すると， A 他 N 文と $\mathrm{B}$ 他 $\mathrm{N}$ 文は， $\mathrm{A}$ 他 $\mathrm{R}$ 文と $\mathrm{B}$ 他 $\mathrm{R}$ 文よりも省略の頻度 が 2 倍近かった。R文は，「を」を省略すると，「が」を

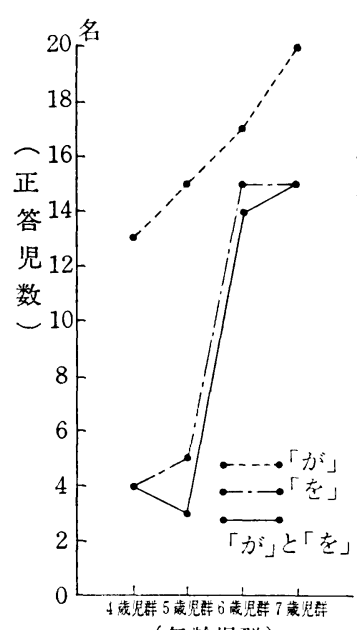

(年舲児群)

FIG. 4 A他R文における 正答児数

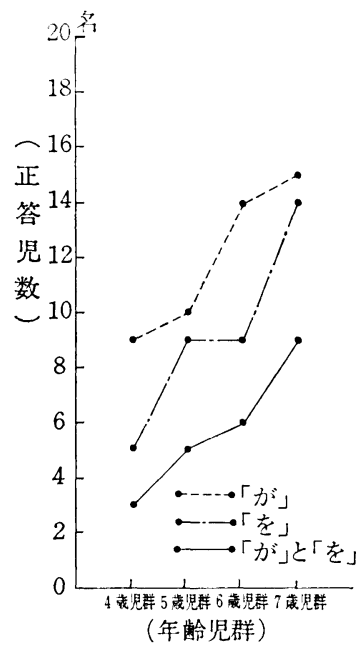

FIG. 6 B他R文における 正答児数

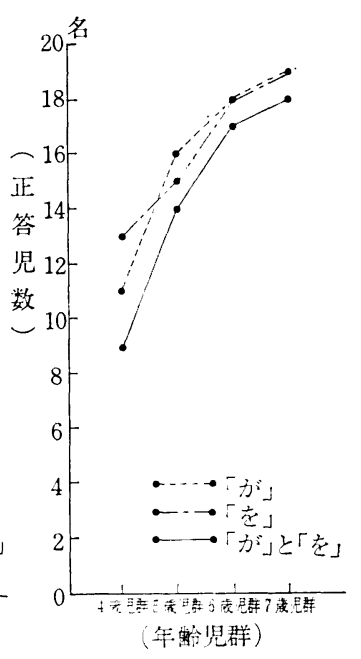

FIG. 5 A 他N文における 正答兄数

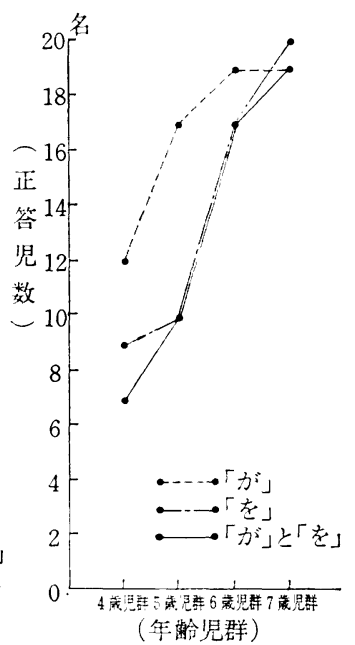

FIG. 7 B他N文における 正答児数
省略したととられる可能性もあり, 意味にあいまいさが でてくる。一方, N文は, 助詞を省略しても意味にあい まいさはない。このことを考えれば，N文に「を」の省 略が多いことは, それなりの意味がある上考えられ, 興 味深い。

（3）「が」と「を」の使用

ここでは,「が」が使用される文と「を」が使用され る文のうち, 共通している, A 他 R文, A 他 $\mathrm{N}$ 文, B他 $\mathrm{R}$ 文， B他 $\mathrm{N}$ 文を取り上げる。

それぞれの文における「が」の正答児数，「を」の正 答児数, および「が」と「を」の両助詞の正答児数を, FIG. 4 ＦIG. 7 に示す。それぞれの文に打ける「が」と 
TABLE 11 「が」と「を」を比較した同年齢 児群の差の検定結果

\begin{tabular}{|c|c|c|c|c|}
\hline \multicolumn{2}{|l|}{ 年齢児群 } & \multirow[b]{2}{*}{5 歳児群 } & \multirow[b]{2}{*}{6 歳児群 } & \multirow[b]{2}{*}{7 歳児群 } \\
\hline $\begin{array}{l}\text { 比較 } \\
\text { した文 } \\
\text { の種類 }\end{array}$ & 4 藏児群 & & & \\
\hline A 他 R文 & $\mathrm{P}<.005$ & $\mathrm{P}<.002$ & N S & $\mathrm{P}<.024$ \\
\hline A 他 N文 & N S & N S & N S & N S \\
\hline B 他 R文 & N S & N S & N S & N S \\
\hline $\mathrm{B}$ 他 $\mathrm{N}$ 文 & N S & $\mathrm{P}<.020$ & N S & N S \\
\hline
\end{tabular}

「を」の正答児数を，同年齢児群で比較した差の検定結 果をTABLE 11 に示す。

これらの結果から，

1） $\mathrm{A}$ 他 $\mathrm{R}$ 文と B 他 $\mathrm{R}$ 文は 4 年齡児群を通して「が」の 正答児数が多く，B他 $\mathrm{N}$ 文は，7歳児群以外は「が」 の正答児数が多以。

2)「が」と「を」の正答児数の差は，A他 R文の 4 歳 児群，5歳児群， 7 歳児群，B他 $\mathrm{N}$ 文の 5 歳児群で, 有意差がみられる。

3）「が」と「を」両助詞の正答児数は， B 他 R文以外 はほほ「を」の正答児数に等しい。

ことが指摘できる。

$\mathrm{R}$ 文の場合，「が」を使用する場合と，「を」を使用す る場合では，まったく逆の関係を表わしており，「が」 と「を」は，2つの対応する関係を表わす格助詞である。 したがって，「が」と「を」がともに正確に使用できな ければ,「が」に正答しても，「が」の表わす関係を正確 に把握しているということはできないし，「を」に正答 しても，「を」の表わす関係を正確に把握しているとい らことはできない。

したがって， A他 $\mathrm{N}$ 文以外の文で「を」より「が」の 正答児数が多かったということは，「が」の使用におい て正答していることが必ずしも「が」の表わす関係を正 確に把握しているということを示すものではない, とい うことができる。

「を」の使用における誤りの種類と頻度を調べると， $\mathrm{A}$ 他 R文と B他 R文は「が」の誤りがもっとも多く, B 他 N文は省略に次いで「が」が多い。この点と上記の結 果を考えあわせると，「が」と「を」の表わす関係を正 確に把握していない場合,「が」を使用する傾向がある ことを示している。

また,「が」と「を」両助詞の正答児数がほぼ「を」 の正答児数に等しいということは，「を」に正答してい
れば「「を」の表わす関係は正確に把握しており，同時 に「が」の表わす関係も把握しているということができ る。

\section{結論}

格助詞「が」と「を」の習得過程に対する手がかりを 得ることを目的とし, 助詞とともに使用される動詞の種 類と, 助詞が使用される文の種類を要因として, これら の助詞の正確な使用の難易を分析した。被験児は, 語い 年齡 4 歳〜 7 歳11か月の幼児および児童である。

まず，各被験児のそれぞれの文の種類における結果を 基礎として, 習得段階の設定を試みた。その結果, 以下 の点が指摘できる。

1)「が」の習得段階を大きく分けると， B 他 R文と B 自 (R)文のいずれにも誤っている段階と，一方または 両方に正答している段階に分かれる。

2)「を」の習得段階を大きく分けると， A 他 R 文と B 他 R文のいずれにも誤っている段階と， A 他 $\mathrm{N}$ 文と $\mathrm{B}$ 他 $\mathrm{N}$ 文には正答し， A 他 R文と B 他 R文の一方または 両方に正答している段階に分かれる。

また, 各年齢児群に分けて文の種類による正答児数の 比較を行い, 正確な使用の難易に影響を及ぼしている要 因を検討した。その結果，以下の点が指摘できる。

1）「が」の正確な使用の容易さに関係しているのは,

(1)「が」が使用される文が，助詞の相違および自動 詞・他動詞の相違などにより, 類似したいくつかの 文で表わすことができる場面をあらわしている文で あるかどうか。

(2) 主語がどんな種類の名詞であるか。

(3) 自動詞とともに使用される場合, その自動詞が対 応する他動詞をもっているかどうか。 であると考えられる。

2）「を」の正確な使用の容易さに関係しているのは, 「を」が使用される文がR文であるか N文であるかで あると考えられる。

3）「を」より「が」が正確な使用が容易であり，「が」 と「を」の表わす関係を正確に把握していない場合, 「が」を使用する傾向がある。

本研究で得られた結果は, 格助詞「が」と「を」の習 得過程を明らかにするための大きな手がかりとなるもの であると考えられる。また, 助詞全体として考える場合, 本研究の結果をそのまま一般化することはできないが, 今後, 助詞の習得過程を考えていく上での示唆を与える ものであると思われる。 
引用文 献

天野 清 1968 就学前児童の言語的コミュニケーショ

ン能力 日本心理学会第32回大会発表論文集, 329

藤田 正・藤友雄睴 1975 幼児の助詞の理解に関する

発達的研究 聴覚言語障害, 4 (1), 24-33.

藤友雄睴 1979 幼児の助詞の習得に関する発達的研究 教育心理学研究, 27, 11-17

秦野悦子 1979 子どもにおける「は」「が」の獲得の

研究 教育心理学研究, 27, 160-168.

Hayashibe, H. 1975 Word order and particles : A developmental study in Japanese. Descriptive and Applied Linguistics (Tokyo : International Christian Univ. ), 8, 1-18.

池 弘子 1979 知能障害児の話しことばに関する研究
一助詞の使用に関して一 心身障害学研究, 3, 57一 66.

井上和子 1976 変形文法と日本語 -上 大修館書店 岩淵悦太郎・村石昭三(編) 1976 幼児の用語 日本放 送出版協会

国立国語研究所 1951 現代語の助詞 - 助動詞一用法々 実例一 秀英出版

久野 暲 1973 日本文法研究 大修館書店

永野 賢 1959 幼児の言語発達について一主として助

詞の習得過程を中心に一 国立国語研究所論集 1

ことばの研究, 383-396.

大久保 愛 1967 幼児言語の発達 東京堂出版

大久保 愛 1973 幼児のことばとおとな 三省堂

(1981年 8 月 10 日受稿)

\title{
ABSTRACT \\ THE ACQUISITION PROCESS OF THE JOSHI (PARTICLES)
}

\author{
-O" and "GA" \\ by \\ Hiroko Ike
}

The purpose of this study was to find the clue clarifying the acquistion process of the JOSHI (particles). This was done by analyzing the difficulty in the JOSHI "GA" and "O" acquired by comparing the kind of sentences using JOSHI.

The subjects were 80 normal children with a vocabulary age between $4: 0$ and $7: 11$.

In order to test the subjects' ability to use JOSHI, 33 incomplete sentences without JOSHI were presented to them using a taperecorder and picture cards. Then, they were asked to repeat while completing the sentence after listening to each incomplete sentence.

The results of this experiment might be summarized as follows:

1. The children with a vocabulary age between 7 : 0 and $7: 11$ could use "GA" and "O" almost perfectly.
2. The ability to use "GA" was acquired earlier than the ability to use "O".

3. The child not knowing the accurate meaning of "GA" and "O" had a trend to use "GA".

4. The dificulty to use "GA" depended on

a) whether the sentence described the situation that could be described by other similar sentences or not.

b) what the kind of noun used as the subject in the sentence.

c) whether the intransitive verb requiring the use of "GA" had a corresponding transitive verb or not.

5. The difficulty to use " $O$ " depending on whether the sentence would be a reversal or nonreversal sentence. 